\title{
PENGARUH KECERDASAN EMOSIONAL TERHADAP \\ HASIL BELAJAR MATEMATIKA SISWA KELAS VIII MTS NEGERI 1 KENDARI
}

\author{
Aisyah Wiyono ${ }^{1)}$, Mustamin Anggo ${ }^{2)}$, Kadir $^{3)}$ \\ ${ }^{1)}$ Alumni Jurusan Pendidikan Matematika, ${ }^{2,3)}$ Dosen Jurusan Pendidikan Matematika \\ FKIP Universitas Halu Oleo: email: aisyahw97@gmail.com; mustaminanggo@gmail.com; \\ kadirraea@yahoo.co.id
}

\begin{abstract}
Abstrak
Penelitian expos fakto ini bertujuan untuk mengetahui pengaruh kecerdasan emosional terhadap hasil belajar matematika siswa Kelas VIII MTs Negeri 1 Kendari. Populasi penelitian ini adalah seluruh siswa kelas VIII MTs Negeri 1 Kendari yang berjumlah 345 siswa yang tersebar dalam sepuluh kelas. Pengambilan sampel dilakukan dengan teknik purposive sampling. Jumlah sampel dalam penelitian ini adalah 67 siswa. Pengambilan data dilakukan dengan dua cara yaitu angket dan tes. Angket digunakan untuk memperoleh data yang berkaitan dengan kecerdasan emosional, sedangkan tes digunakan untuk mengambil data hasil belajar matematika siswa. Teknik analisis data yang digunakan adalah analisis statistik deskriptif dan statistik inferansial. Dari hasil analisis data dan pembahasan diperoleh kesimpulan: kecerdasan emosional mempunyai pengaruh yang signifikan terhadap hasil belajar matematika siswa kelas VIII MTs Negeri 1 Kendari, besarnya pengaruh kecerdasan emosional yaitu sebesar $13,6 \%$, sedangkan sisanya sebesar $86,4 \%$ dipengaruhi oleh faktor lainnya yang tidak diteliti dalam penelitian ini.
\end{abstract}

Kata Kuci: kecerdasan emosional, hasil belajar matematika

\section{THE INFLUENCE OF EMOTIONAL INTELLIGENCE ON STUDENTS MATHEMATICS LEARNING OUTCOMES CLASS VIII MTS NEGERI 1 KENDARI}

\begin{abstract}
This study expos facto aims to determine the influence of emotional intelligence on students mathematics learning outcomes class VIII MTs Negeri 1 Kendari. The population of this study is all students of class VIII MTs Negeri 1 Kendari which amounted to 345 students spread in ten classes. Sampling was done by purposive sampling technique. The number of samples in this study is 67 students. The data were collected in two ways: questionnaire and test. Questionnaires are used to obtain data related to emotional intelligence, whereas tests are used to retrieve student learning mathematics data. Data analysis techniques used are descriptive statistical analysis and inferential statistics. From the results of data analysis and discussion obtained conclusion: emotional intelligence has a significant influence on the results of learning mathematics students VIII MTs Negeri 1 Kendari, the magnitude of the influence of emotional intelligence that is equal to $13.6 \%$, while the remaining of $86.4 \%$ influenced by other factors not examined in this study.
\end{abstract}

Keywords: emotional intelligence, mathematics learning outcomes 


\section{Pendahuluan}

Salah satu upaya untuk meningkatkan sumber daya manusia adalah melalui pendidikan. Pendidikan memegang peranan yang amat penting untuk menjamin hidup suatu negara dan bangsa karena pendidikan merupakan wahana untuk meningkatkan dan mengembangkan kualitas sumber daya manusia. Dalam UU Sisdiknas No. 20 tahun 2003 Bab 1, pasal 1 , ayat 1 tertulis bahwa "Pendidikan adalah usaha sadar dan terencana untuk mewujudkan suasana belajar dan proses pembelajaran, agar peserta didik secara aktif mengembangkan potensinya sendiri untuk memiliki kekuatan spiritual keagamaan, pengendalian diri, kepribadian, kecerdasan, akhlak mulia serta keterampilan yang diperlukan dirinya, masyarakat, bangsa dan negara".

Pendidikan adalah sebuah proses untuk mengubah jati diri seorang siswa untuk lebih maju. Untuk itu dalam pendidikan terdapat kegiatan belajar mengajar sebagai pokoknya. Ada dua komponen utama yang berperan dalam kegiatan belajar mengajar, yaitu guru dan siswa. Sekolah sebagai lembaga formal merupakan sarana dalam rangka mencapai tujuan pendidikan.

Belajar merupakan suatu proses yang menimbulkan terjadinya perubahan atau pembaharuan dalam tingkah laku dan kecakapan. Hasil dari proses belajar tersebut tercermin dalam hasil belajarnya. Menurut Purwanto (Thobroni, 2013: 31), berhasil atau tidaknya perubahan tersebut dipengaruhi oleh berbagai faktor yang digolongkan menjadi dua golongan, yaitu faktor yang ada pada diri organisme tersebut atau yang disebut faktor individual, dan faktor yang ada diluar individu yang disebut faktor sosial.

Faktor individu meliputi faktor kematangan atau pertumbuhan, kecerdasan, latihan dan ulangan, motivasi, dan faktor pribadi. Sedangkan termasuk ke dalam faktor sosial antara lain faktor keluarga, guru dan cara mengajarnya, alat-alat yang digunakan dalam pembelajaran, lingkungan dan kesempatan yang tersedia, serta faktor motivasi sosial.

Kecerdasan atau inteligensi merupakan salah satu faktor yang dapat mempengaruhi hasil belajar siswa. Setiap siswa memiliki tingkat kecerdasan yang berbeda-beda. Menurut Prawira (2013: 151), kecerdasan adalah kemampuan mental seseorang merespons dan menyelesaikan problem dari hal-hal yang bersifat kuantitatif dan fenomenal, seperti matematika, fisika, datadata sejarah, dan sebagainya. Sedangkan ukuran kecerdasan yang disebut dengan IQ merupakan perbandingan kemampuan antara umur mental dan umur kronologis. Kecerdasan seperti ini penting dalam dunia akademis dan menjadi modal utama dunia perekayasaan dan teknologi. Namun, menurut Suharsono (Prawira, 2013: 151), membekali anak dengan IQ tinggi saja tidak dapat menjamin anak bisa hidup sukses. Sebab, IQ tinggi baru merupakan bekal yang baik untuk dapat mengenal dan merespons alam semesta. Tetapi, IQ tinggi belum dapat mengakomodasi untuk mengenal dan memahami diri sendiri dan sesamanya.

Jenis kecerdasan untuk mengenal dan memahami diri sendiri dan sesamanya disebut dengan istilah kecerdasan emosional disingkat EI (Emotional Intelligence). Salovey dan Meyer (2004: 13) menyatakan bahwa kecerdasan emosional sebagai himpunan bagian dari kecerdasan sosial yang melibatkan kemampuan memantau perasaan emosi baik pada diri sendiri maupun pada orang lain, memilah-milah semuanya, dan menggunakan informasi ini untuk membimbing pikiran dan tindakan. Hal ini berarti bahwa kecerdasan emosional merupakan kemampuan siswa untuk dapat mengenali emosi diri, mengendalikan emosi diri, memotivasi diri, memahami emosi orang lain dan kemampuan untuk dapat membina hubungan baik dengan orang lain.

Matematika merupakan salah satu mata pelajaran yang memiliki peranan penting, baik dalam kehidupan akademis ataupun kehidupan sehari-hari. Setiap siswa mempunyai pandangan yang berbeda tentang pelajaran matematika. Ada yang memandang matematika sebagai mata pelajaran yang menyenangkan dan ada juga yang memandang matematika sebagai pelajaran yang sulit. Berbagai pandangan tersebut dapat berdampak pada hasil belajar yang mereka peroleh. Bagi siswa yang menganggap matematika menyenangkan, maka akan tumbuh motivasi dalam diri siswa tersebut untuk mempelajari matematika dan optimis dalam menyelesaikan masalah-masalah yang bersifat menantang dalam pelajaran matematika. Sebaliknya, bagi yang 
menganggap matematika sebagai pelajaran sulit, maka siswa tersebut akan bersikap pesimis dalam menyelesaikan masalah matematika dan kurang termotivasi untuk mempelajarinya.

Masalah-masalah dalam mata pelajaran matematika membutuhkan tahap penyelesaian yang sistematis serta menuntut siswa untuk menggunakan logika dalam menyelesaikannya, sehingga dalam memahami dan menyelesaikan masalah matematika membutuhkan konsentrasi, kesabaran, dan ketelitian. Untuk mengelola konsentrasi, kesabaran dan ketelitian dibutuhkan motivasi dan pengelolaan emosi yang kuat, sehingga siswa tidak mudah putus asa dan menyerah ketika belum dapat menemukan jawaban penyelesaian yang tepat. Sikap memotivasi, ketekunan, kegigihan dan pengelolaan diri untuk dapat menghayati setiap materi pelajaran cenderung mengarah kepada kecerdaan emosional.

Kecerdasan emosional berkaitan dengan bagaimana siswa mengenali dan mengontrol emosi diri, sehingga berdampak positif pada saat mengikuti pembelajaran. Yusuf (2004: 181) mengemukakan bahwa emosi yang positif akan mempengaruhi siswa untuk berkonsetrasi terhadap aktivitas belajar, seperti memperhatikan penjelasan guru, membaca buku, aktif dalam berdiskusi, mengerjakan tugas, dan disiplin dalam belajar.

Apabila siswa dapat mengenali, mengelola emosi serta memotivasi diri sendiri dalam proses belajar matematika serta mampu berempati dan membina hubungan yang baik dengan teman dan guru maka akan mendorong siswa untuk memiliki hasil belajara matematika yang baik. Keterampilan dasar emosional tidak dapat dimiliki secara tiba-tiba, tetapi membutuhkan proses dalam mempelajarinya dan lingkungan yang membentuk kecerdasan emosional tersebut besar pengaruhnya. Hal positif akan diperoleh bila anak diajarakan keterampilan dasar kecerdasan emosional, secara emosional akan lebih cerdas, penuh pengertian, mudah menerima perasaan-perasaan dan lebih banyak pengalaman dalam memecahkan permasalahannya sendiri.

Selama proses pembelajaran, kecerdasan emosional diperlukan oleh siswa untuk memahami pelajaran yang disampaikan oleh guru, karena intelektualitas saja tidak dapat berfungsi dengan sebaik-baiknya tanpa adanya penghayatan emosi pada setiap mata pelajaran. Menurut Goleman (2016: 42) IQ hanya mempunyai peran sekitar $20 \%$ dalam menentukan prestasi individu, $80 \%$ sisanya ditentukan oleh faktor-faktor lain termasuk kecerdasan emosional (EI). Selain itu, Goleman (2016: 45) menyatakan bahwa kecerdasan emosional menentukan seberapa baik siswa mampu menggunakan keterampilanketerampilan lain manapun yang dimilikinya, termasuk intelektual yang belum terasah.

Kecerdasan emosional bertumpu pada hubungan antara perasaan, watak, dan naluri moral yang mencakup pengendalian diri, semangat dan ketekunan, kemampuan menyesuaikan diri, kemampuan memecahkan masalah pribadi, pengendalian amarah serta kemampuan untuk memotivasi diri sendiri terutama dalam proses pembelajaran. Dalam proses pembelajaran terjadi suatu perubahan kemampuan yang dimiliki oleh siswa dalam berbagai bidang, dan kemampuan itu diperoleh karena adanya usaha belajar.

Berdasarkan pengamatan dan wawancara pada guru matematika di kelas VIII MTs Negeri 1 Kendari, diindikasikan bahwa siswa kurang dapat mengontrol dan mengelola emosinya. Hal ini ditunjukkan dengan sikap siswa selama mengikuti pembelajaran. Selama proses pembalajaran siswa terlihat kurang bersemangat dalam mengikuti pembelajaran matematika, kurang memperhatikan penjelasan materi dari guru, dan siswa masih kurang bersungguh-sungguh dalam mengerjakan soal yang diberikan. Selain itu, hasil belajar matematika siswa kelas VIII MTs Negeri 1 Kendari masih rendah. Hal ini disampaikan oleh guru bidang studi matematika bahwa hasil ulangan pelajaran matematika siswa secara mayoritas masih dibawah Kriteria Ketuntasan Minimum (KKM) sebesar 75.

Rendahnya hasil belajar matematika siswa kelas VIII MTs Negeri 1 Kendari diduga karena siswa tidak memperhatikan penjelasan dari guru dan malas dalam mengerjakan soal matematika sehinggga kurang termotivasi untuk memahami pelajaran. Untuk mencapai prestasi yang tinggi pada mata pelajaran matematika tidak hanya diperlukan IQ yang tinggi saja, namun siswa juga harus memiliki kecerdasan emosional yang baik. Menurut Goleman (2016: xiii), jika IQ lebih mengarah kepada kecerdasan kognitif, maka kecerdasan emosional lebih mengarah kepada sikap, motivasi, ketekunan, 
kegigihan dan pengelolaan emosi diri untuk dapat menghayati setiap materi pelajaran.

Menurut Mustaqim (2012: 152), kecerdasan emosional dapat berpengaruh dalam proses dan keberhasilan belajar siswa, tanpa adanya kecerdasan emosional siswa akan mudah menyerah, tidak memiliki motivasi belajar dan tidak pandai memusatkan perhatian pada materi pembelajaran. Siswa yang memiliki kecerdasan emosional yang tinggi akan lebih terampil dalam menenangkan diri dan memusatkan perhatian dalam memahami materi pelajaran, memiliki hubungan yang lebih baik dengan orang lain, lebih cakap memahami orang, memiliki persahabatan yang baik dengan orang lain, dan memiliki hasil belajar yang lebih baik. Kecerdasan emosional bekerja secara sinergi dengan kecerdasan intelektual. Seseorang akan berprestasi tinggi bila memiliki keduanya. Namun, apabila seseorang yang tingkat kecerdasan emosionalnya kurang akan mempengaruhi kecerdasan intelektualnya.

\section{Metode}

Penelitian ini menggunakan pendekatan penelitian kuantitatif dengan jenis penelitian expost facto. Penelitian expost facto merupakan penelitian dengan melakukan penyelidikan secara empiris yang sistematik, dimana peneliti tidak mempunyai kontrol langsung terhadap variabel-variabel bebas, karena fenomena sukar dimanipulasi (Siregar, 2013: 4). Penelitian ini dilaksanakan di MTs Negeri 1 Kendari. Waktu penelitian ini adalah pada semester genap tahun pelajaran 2016/2017.

Sampel adalah sebagian atau wakil populasi yang diteliti. Populasi dalam penelitian ini adalah seluruh siswa kelas VIII MTs Negeri 1 Kendari tahun ajaran 2016/2017 sebanyak 10 kelas, dengan jumlah keseluruhan siswa sebanyak 345 orang dengan rincian dapat dilihat pada Tabel 1.

Tabel 1

Data Siswa Kelas VIII MTs Negeri 1 Kendari

\begin{tabular}{|c|c|c|c|}
\hline Kelas & Jumlah Siswa & Kelas & Jumlah Siswa \\
\hline VIII $_{1}$ & 35 & VIII $_{6}$ & 36 \\
\hline VIII $_{2}$ & 34 & VIII $_{7}$ & 34 \\
\hline $\mathrm{VIII}_{3}$ & 35 & $\mathrm{VIII}_{8}$ & 35 \\
\hline $\mathrm{VIII}_{4}$ & 36 & VIII $_{9}$ & 33 \\
\hline $\mathrm{VIII}_{5}$ & 34 & $\mathrm{VIII}_{10}$ & 33 \\
\hline
\end{tabular}

Teknik pengambilan sampel yang digunakan adalah Purposive Sampling, yaitu responden yang terpilih menjadi anggota sampel atas dasar pertimbangan peneliti sendiri (Dermawan, 2013: 152). Populasi dalam penelitian ini terbagi dalam 10 kelas, dimana terdapat 1 kelas unggulan (VIII-5) dan 9 kelas reguler (VIII-1, VIII-2, VIII-3, VIII-4, VIII-6, VIII-7, VIII-8, VIII-9, VIII-10). Agar sampel dapat mewakili seluruh populasi maka diambil sampel sebanyak 2 kelas yaitu kelas VIII-5 (34 siswa) dan kelas VIII-9 (33 siswa) yang berjumlah 67 siswa.

Variabel yang digunakan dalam penelitian ini ialah variabel bebas dan variabel terikat. Variabel bebas disimbolkan dangan $\mathrm{X}$ menyatakan kecerdasan emosional, dan variabel terikat disimbolkan dengan Y menyatakan hasil belajar matematika siswa. Desain hubungan antara variabel dapat dilihat seperti gambar berikut :

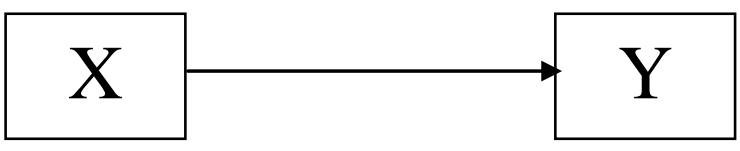

Gambar 1. Desain Penelitian

Teknik pengumpulan data yang digunakan pada penelitian ini ada dua, yaitu kuesioner dan tes. Kuesioner merupakan teknik pengumpulan data yang dilakukan dengan cara memberi seperangkat pertanyaan atau pernyataan tertulis kepada responden untuk dijawabnya (Sugiyono 2009: 142). Peneliti dalam teknik ini akan memberikan angket 
kepada setiap siswa yang dijadikan sampel penelitian. Dengan metode ini dimaksudkan untuk memperoleh data yang berkaitan dengan kecerdasan emosional siswa kelas VIII MTs Negeri 1 Kendari.

Tes merupakan himpunan pertanyaan yang harus dijawab, harus ditanggapi, atau tugas yang harus dilaksanakan oleh orang yang dites (Jihad, 2013: 67). Tes digunakan untuk mengukur sejauh mana seorang siswa telah menguasai pelajaran yang disampaikan terutama meliputi aspek pengetahuan dan keterampilan. Tes dalam penelitian ini menggunakan tes bentuk uraian untuk memperoleh data yang berkaitan dengan hasil belajar matematika siswa.

Instrumen yang digunakan dalam penelitian ini berupa angket kecerdasan emosional dan tes hasil belajar matematika. Angket yang digunakan adalah jenis angket tetutup. Dalam angket ini tugas responden adalah memilih satu jawaban dari kemungkinankemungkinan jawaban yang telah disediakan. Kriteria yang digunakan pada instrumen angket kecerdasan emosional ini adalah skala likert, yaitu pernyataan-pernyataan yang menempatkan individu pada situasi yang menggambarkan dirinya dengan memilih salah satu dari empat alternatif jawaban yang disediakan, yaitu sangat sering (SS), sering (S), jarang (JR), dan tidak pernah (TP). Intrumen yang digunakan dalam penelitian ini adalah angket kecerdasan emosional yang telah ada sebelumnya dengan nilai koefisien reliabilitas sebesar 0,837 (Imron, 2016: 91).

Tes digunakan untuk mengetahui data hasil belajar matematika siswa. Bentuk tes yang digunakan berupa uraian pada materi lingkaran yang disusun berdasarkan kompetensi dasar dan indikator yang telah diajarkan oleh guru bidang studi matematika kelas VIII MTs Negeri 1 Kendari. Tes hasil belajar terdiri dari delapan soal, setiap butir soal memiliki skor yang berbeda berdasarkan tingkat kesulitan soal dan langkah-langkah dalam menjawab soal tersebut. Skor perolehan siswa kemudian dikonversi ke skala 100 dengan aturan: nilai perolehan siswa $=\frac{\text { skor perolehan siswa }}{\text { skor maksimal }} \times 100$ . Nilai perolehan siswa tersebut merupakan data dalam penelitian ini.

Uji validitas penelitian dilakukan menggunakan metode Pearson Product Moment dengan mengkorelasikan antara skor yang didapat siswa pada suatu butir soal dengan skor total yang didapat. Rumus yang digunakan sebagai berikut :

$$
r_{X Y}=\frac{N \sum X Y-\left(\sum X\right)\left(\sum Y\right)}{\sqrt{\left\{N \sum X^{2}-\left(\sum X^{2}\right),\left(N \sum Y^{2}-\left(\sum Y^{2}\right)\right\}\right.}}
$$

(Sugiyono, 2009: 183)

Keterangan :

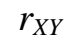

$r_{X Y}$

Koefisien korelasi antara variabel $\mathrm{X}$ dan Variabel Y

$X$

item

Y

total

$N$

Jumlah responden

Adapun kriteria pengambilan keputusan untuk menentukan valid atau tidaknya instrumen penelitian adalah jika $r$ hitung sama dengan atau lebih besar dari harga $r$ tabel pada taraf signifikan 5\%, maka butir instrumen yang dimaksud dikatakan valid. Jika $r$ hitung diperoleh lebih kecil dari $r$ tabel pada taraf signifikan 5\%, maka butir instrumen yang dimaksud dikatakan tidak valid.

Perhitungan reliabilitas harus dilakukan hanya pada item-item yang sudah memiliki validitas. Analisis reliabilitas terhadap item-item yang sahih dilakukan dengan teknik Alpha

Cronbach, dengan rumus sebagai berikut :

$$
r_{11}=\left(\frac{n}{n-1}\right)\left(1-\frac{\sum \sigma_{i}^{2}}{\sigma_{t}^{2}}\right)
$$

(Siregar,

$$
\text { 2013: 58) }
$$

dengan :

$\mathrm{r}_{11}$

Reliabilitas instrumen

$\mathrm{n}$

banyaknya butir pertanyaan atau banyaknya soal yang valid

$$
\begin{gathered}
\sum_{\sigma_{t}^{2}} \sigma_{i}^{2}=\text { jumlah varians skor tiap-tiap butir } \\
=
\end{gathered}
$$

varians total

Instrumen dikatakan reliabel dengan menggunakan teknik ini jika koefisien reliabilitasnya $\left(\mathrm{r}_{11}\right)>0,6$ (Siregar, 2013: 57) 
Teknik analisis data yang digunakan dalam penelitian ini adalah statistik deskriptif dan statistif inferensial. Statistik deskriptif digunakan untuk mendeskripsikan karakteristik skor responden untuk masing-masing variabel. Untuk keperluan tersebut digunakan tabel distribusi frekuensi dengan analisis persentase, standar deviasi, mean, nilai maksimum, nilai minimum, range (rentang skor), koefisien varians. Statistika inferensial digunakan untuk menguji hipotesis penelitian, yaitu dengan menggunakan analisis regresi. Sebelum melakukan analisis data maka terlebih dahulu dilakukan uji prasyarat analisis yang meliputi uji normalitas dan uji linearitas. Uji normalitas dilakukan untuk melihat apakah data yang diperoleh dalam penelitian ini berasal dari populasi yang berdistribusi normal atau tidak. Sedangkan uji linearitas dilakukan untuk mengetahui apakah kecerdasan emosional dan hasil belajar matematika mempunyai hubungan garis linear.

\section{Hasil}

\section{Analisis validitas dan reliabilitas instrumen}

Hasil analisis instrumen tes hasil belajar matematika siswa terdiri dari analisis validitas dan reliabilitas yang didasarkan pada hasil penelaian uji coba kepada 30 siswa kelas IX-1 MTs Negeri 1 Kendari. Berdasarkan perhitungan validitas tes hasil belajar matematika dengan bantuan Microsoft Office Excel 2007 diperoleh semua item tes hasil belajar dinyatakan valid. Hasil perhitungan selengkapnya dapat dilihat pada Tabel 2 .

Tabel 2

Analisis Hasil Validitas Intrumen Tes Hasil Belajar Matematika

\begin{tabular}{|c|c|c|c|}
\hline Butir Soal & $\mathrm{r}_{\text {hitung }}$ & $\mathrm{r}_{\text {tabel }}$ & Keterangan \\
\hline 1 & 0,4106 & 0,374 & Valid \\
\hline 2 & 0,399 & 0,374 & Valid \\
\hline 3 & 0,397 & 0,374 & Valid \\
\hline 4 & 0,409 & 0,374 & Valid \\
\hline 5 & 0,4796 & 0,374 & Valid \\
\hline 6 & 0,577 & 0,374 & Valid \\
\hline 7 & 0,761 & 0,374 & Valid \\
\hline 8 & 0,8144 & 0,374 & Valid \\
\hline
\end{tabular}

Butir soal yang dinyatakan valid selanjutnya dilakukan uji reliabilitas. Dalam melakukan uji reliabilitas, data uji coba instrumen hasil belajar matematika diolah menggunakan bantuan software statistik SPSS. Berdasarkan hasil uji reliabilitas, diketahui Alpha Cronbach sebesar 0,639. Hal ini menunjukkan bahwa intrumen tes hasil belajar matematika ini reliabel.

\section{Analisis deskriptif}

Analisis deskriptif dimaksudkan untuk memberikan gambaran tentang karakteristik responden dari masing-asing variabel penelitian yaitu kecerdasan emosional (X) dan hasil belajar matematika (Y). Pendeskripsian karakteristik tersebut dapat dilihat melalui rata-rata hitung (mean), median, standar deviasi, nilai maksimum, dan nilai minimum yang dapat dilihat pada Tabel 3 . 
Tabel 3.

Analisis Deskriptif Kecerdasan Emosional Terhadap

Hasil Belajar Matematika Siswa Kelas VIII-5

\begin{tabular}{|l|l|r|r|}
\hline \multicolumn{2}{|c|}{} & \multicolumn{1}{|c|}{$\begin{array}{c}\text { Kecerdasan } \\
\text { Emosional }\end{array}$} & \multicolumn{1}{c|}{ HBM } \\
\hline \multirow{2}{*}{$\mathrm{N}$} & Valid & 34 & 34 \\
\cline { 2 - 4 } & Missing & 0 & 0 \\
\hline Mean & 136,44 & 71,876 \\
\hline Median & 135,00 & 78,785 \\
\hline Std. Deviation & 11,090 & 17,351 \\
\hline Minimum & 116 & 21,21 \\
\hline Maximum & 155 & 92,42 \\
\hline
\end{tabular}

Hasil analisis deskripsi pada tabel 3, variabel kecerdasan emosional dapat dijelaskan dari sampel yang diambil sebanyak 34 siswa bahwa nilai rata-rata (mean) yang diperoleh sebesar 136,44 dengan median 135,00. Artinya skor kecerdasan emosional pada angket secara keseluruhan diatas rata-rata. Skor tertinggi diperoleh sebesar 155, skor terendah sebesar 116 dengan standar deviasi 11,090. Pada variabel hasil belajar matematika dari 34 siswa diperoleh nilai rata-rata (mean) sebesar 71,876 dengan median sebesar 78,785. Skor tertinggi diperoleh sebasar 92,42, skor terendah sebesar 21,21 dengan standar deviasi 17,351.

Tabel 4.

Analisis Deskriptif Kecerdasan Emosional Terhadap Hasil Belajar Matematika Siswa Kelas VIII-9

\begin{tabular}{|l|l|r|r|}
\hline \multicolumn{2}{|c|}{} & \multicolumn{1}{|c|}{$\begin{array}{c}\text { Kecerdasan } \\
\text { Emosional }\end{array}$} & \multicolumn{1}{c|}{ HBM } \\
\hline \multirow{2}{*}{$\mathrm{N}$} & Valid & 33 & 33 \\
\cline { 2 - 4 } & Missing & 0 & 0 \\
\hline Mean & 134,18 & 52,799 \\
\hline Median & 135,00 & 53,030 \\
\hline Std. Deviation & 10,110 & 8,901 \\
\hline Minimum & 118 & 39,39 \\
\hline Maximum & 153 & 74,24 \\
\hline
\end{tabular}

Hasil analisis deskripsi pada tabel 4, variabel kecerdasan emosional dapat dijelaskan dari sampel yang diambil sebanyak 33 siswa bahwa nilai rata-rata (mean) yang diperoleh sebesar 134,18 dengan median 135,00. Artinya skor kecerdasan emosional pada angket secara keseluruhan diatas rata-rata. Skor tertinggi diperoleh sebesar 153, skor terendah sebesar 118 dengan standar deviasi 10,110. Pada variabel hasil belajar matematika dari 33 siswa diperoleh nilai rata-rata (mean) sebesar 52,799 dengan median sebesar 53,030. Skor tertinggi diperoleh sebasar 74,24, skor terendah sebesar 39,39 dengan standar deviasi 8,901. 
Tabel 5

Analisis Deskriptif Kecerdasan Emosional Terhadap Hasil Belajar Matematika Siswa Kelas VIII MTs Negeri 1 Kendari

\begin{tabular}{|l|l|r|r|}
\hline \multicolumn{2}{|c|}{} & \multicolumn{1}{|c|}{$\begin{array}{c}\text { Kecerdasan } \\
\text { Emosional }\end{array}$} & \multicolumn{2}{|c|}{ HBM } \\
\hline \multirow{2}{*}{$\mathrm{N}$} & Valid & 67 & 67 \\
\cline { 2 - 4 } & Missing & 0 & 0 \\
\hline Mean & 135,33 & 62,480 \\
\hline Median & 135,00 & 60,610 \\
\hline Std. Deviation & 10,599 & 16,772 \\
\hline Minimum & 116 & 21,21 \\
\hline Maximum & 155 & 92,42 \\
\hline
\end{tabular}

Hasil analisis deskripsi pada Tabel 5, variabel kecerdasan emosional dapat dijelaskan dari sampel yang diambil sebanyak 67 siswa bahwa nilai rata-rata (mean) yang diperoleh sebesar 135,33 dengan median 135,00. Artinya skor kecerdasan emosional pada angket secara keseluruhan diatas rata-rata. Skor tertinggi diperoleh sebesar 155, skor terendah sebesar 116 dengan standar deviasi 10,599. Pada variabel hasil belajar matematika dari 67 siswa diperoleh nilai rata-rata (mean) sebesar 62,480 dengan median sebesar 60,610. Skor tertinggi diperoleh sebasar 92,42, skor terendah sebesar 21,21 dengan standar deviasi 16,772.

Data kecerdasan emosional diperoleh dengan menggunakan angket kecerdasan emosional yang terdiri dari 45 butir pernyataan. Rentang skor yang digunakan untuk masingmasing item adalah 1 sampai 4 . Distribusi nilai angket kecerdasan emosional dapat dilihat pada Tabel 6.

Tabel 6

Kategori Tingkat Kecerdasan Emosional Siswa Kelas VIII MTs Negeri 1 Kendari

\begin{tabular}{|c|c|c|c|c|c|}
\hline \multirow{2}{*}{ Kategori } & \multirow{2}{*}{ Interval } & \multicolumn{2}{|c|}{ Kelas VIII-5 } & \multicolumn{2}{c|}{ Kelas VIII-9 } \\
\cline { 3 - 6 } & Frekuensi & $\begin{array}{c}\text { Persentase } \\
(\%)\end{array}$ & Frekuensi & $\begin{array}{c}\text { Persentase } \\
(\%)\end{array}$ \\
\hline Sangat Tinggi & $153<\mathrm{X} \leq 180$ & 2 & 5,88 & 0 & 0 \\
\hline Tinggi & $126<\mathrm{X} \leq 153$ & 26 & 76,47 & 25 & 75,76 \\
\hline Sedang & $99<\mathrm{X} \leq 126$ & 6 & 17,65 & 8 & 24,24 \\
\hline Rendah & $72<\mathrm{X} \leq 99$ & 0 & 0 & 0 & 0 \\
\hline Sangat Rendah & $45<\mathrm{X} \leq 72$ & 0 & 0 & 0 & 0 \\
\hline \multicolumn{2}{|r|}{ Jumlah } & 34 & 100 & 33 & 100 \\
\hline
\end{tabular}

Berdasarkan Tabel 6, di atas dapat dilihat bahwa kecerdasan emosional siswa kelas VIII-5 terdiri atas 2 siswa $(5,88 \%)$ memiliki kecerdasan emosional kategori sangat tinggi, 26 siswa $(76,47 \%)$ memiliki kecerdasan emosional kategori tinggi dan 6 siswa $(17,65 \%)$ memiliki kecerdasan emosional kategori sedang. Untuk siswa kelas VIII-9 terdiri atas 25 siswa $(75,76 \%)$ memiliki kecerdasan emosional kategori tinggi, dan 8 siswa $(24,24 \%)$ memiliki kecerdasan emosional kategori sedang. Secara keseluruhan kecerdasan emosional siswa kelas VIII MTs Negeri 1 Kendari terdiri atas 2 siswa $(2,98 \%)$ memiliki kecerdasan emosional kategori sangat tinggi, 51 siswa $(76,12 \%)$ memiliki kecerdasan emosional kategori tinggi, dan 14 siswa $(20,90 \%)$ memiliki kecerdasan emosional kategori sedang.

Data hasil belajar matematika diperoleh melalui tes secara langsung oleh peneliti. Distribusi frekuensi hasil belajar matematika dapat dilihat pada Tabel 7. 
Tabel 7

Distribusi Frekuensi Hasil Belajar Matematika Siswa

Kelas VIII MTs Negeri 1 Kendari

\begin{tabular}{|l|l|l|l|l|l|}
\hline \multirow{2}{*}{ Kriteria } & \multirow{2}{*}{ Interval } & \multicolumn{2}{c|}{ Kelas VIII-5 } & \multicolumn{2}{c|}{ Kelas VIII-9 } \\
\cline { 3 - 6 } & & Frekuensi & $\begin{array}{c}\text { Persentase } \\
(\%)\end{array}$ & Frekuensi & $\begin{array}{c}\text { Persentase } \\
(\%)\end{array}$ \\
\hline Sangat Baik & $85<\mathrm{Y} \leq 100$ & 1 & 2,94 & 0 & 0 \\
\hline Baik & $70<\mathrm{Y} \leq 85$ & 21 & 61,77 & 2 & 6,06 \\
\hline Cukup & $55<\mathrm{Y} \leq 70$ & 9 & 26,47 & 12 & 36,36 \\
\hline Kurang & $\mathrm{Y} \leq 55$ & 3 & 8,82 & 19 & 57,58 \\
\hline Jumlah & 34 & 100 & 33 & 100 \\
\hline
\end{tabular}

Berdasarkan Tabel 7, distribusi frekuensi hasil belajar matematika siswa kelas VIII-5 MTs Negeri 1 Kendari menunjukan bahwa siswa yang hasil belajarnya sangat baik sebanyak 1 siswa $(2,94 \%)$, siswa yang hasil belajarnya baik sebanyak 21 siswa $(61,77 \%)$, siswa yang hasil belajarnya cukup sebanyak 7 siswa (26,47\%), sedangkan siswa yang hasil belajarnya kurang sebanyak 3 siswa $(8,82 \%)$. Kelas VIII-9 menunjukan bahwa siswa yang hasil belajarnya baik diperoleh sebanyak 2 siswa $(6,06 \%)$, siswa yang hasil belajarnya cukup sebanyak 12 siswa $(36,36 \%)$, sedangkan siswa yang hasil belajarnya kurang sebanyak 19 siswa $(57,58 \%)$. Dengan demikian secara keseluruhan hasil belajar matematika siswa kelas VIII MTs Negeri 1 Kendari menunjukan bahwa siswa yang hasil belajarnya sangat baik sebanyak 1

siswa (1,49\%), siswa yang hasil belajarnya baik sebanyak 23 siswa $(34,33 \%)$, siswa yang hasil belajarnya cukup sebanyak 21 siswa $(31,34 \%)$, sedangkan siswa yang hasil belajarnya kurang sebanyak 22 siswa $(32,84 \%)$.

\section{Uji prasyarat data}

Data

yang telah dikumpulkan selanjutnya di uji prasyarat analisis yang meliputi uji normalitas dan uji linearitas. Uji normalitas data merupakan salah satu prasyarat untuk melakukan uji hipotesis yang dimaksudkan untuk mengetahui apakah data tersebut berdistribusi normal atau tidak. Uji statistik yang digunakan adalah uji Kolmogorov-Smirnov dengan menggunakan aplikasi SPSS yang berdasarkan data nilai angket kecerdasan emosional dan hasil belajar matematika siswa hasil perhitungan dapat dilihat pada Tabel 8.

\section{Tabel 8}

Hasil Analisis Statistik Uji Normalitas Data Kecerdasan Emosional dan Hasil Belajar Matematika Siswa Kelas VIII MTs Negeri 1 Kendari

\begin{tabular}{|c|c|c|c|}
\hline & Kecerdasan Emosional & HBM \\
\hline \multicolumn{2}{|l|}{$\mathrm{N}$} & 67 & 67 \\
\hline \multirow[t]{2}{*}{ Normal parameter } & Mean & 135,33 & 62,480 \\
\hline & Std. Deviation & 10,599 & 16,772 \\
\hline \multicolumn{2}{|c|}{ Kolmogorov-Smirnov Z } & 0,537 & 1,088 \\
\hline \multicolumn{2}{|c|}{ Asymp. Sign. (2-tailed) } & 0,935 & 0,187 \\
\hline
\end{tabular}

Hasil analisis statistik uji normalitas data pada Tabel 8, terlihat bahwa nilai Asymp. Sign. (2-tailed) untuk variabel kecerdasan emosional diperoleh sebesar 0,935. Nilai signifikan ini lebih besar dari taraf nyata $\alpha=$ $0,05(0,935>0,05)$ maka dapat disimpulkan bahwa sampel variabel kecerdasan emosional berasal dari populasi yang berdistribusi normal.
Sedangkan variabel hasil belajar matematika siswa diperoleh nilai Asymp. Sign. (2-tailed) sebesar 0,187. Nilai signifikan ini lebih besar dari taraf nyata $\alpha=0,05(0,187>0,05)$ maka dapat disimpulkan bahwa sampel variabel hasil belajar matematika berasal dari populasi yang berdistribusi normal. 
Uji prasyarat selanjutnya adalah uji linearitas. Uji linearitas bertujuan untuk mengetahui apakah dua variabel mempunyai hubungan yang linear atau tidak secara signifikan. Untuk uji linearitas pada penelitian ini menggunakan bantuan SPSS. Hasil analisisnya dapat di lihat pada Tabel 9.

\section{Tabel 9}

Hasil Uji Linearitas Variabel Kecerdasan Emosional dan Hasil Belajar Matematika Siswa

\begin{tabular}{|l|l|l|l|}
\hline Hubungan & Sig. & $\alpha=0,05$ & Keterangan \\
\hline X terhadap Y & 0,606 & 0,05 & Linear \\
\hline
\end{tabular}

Berdasarkan Tabel 9, dapat dilihat bahwa hubungan antara $\mathrm{X}$ dan $\mathrm{Y}$ berhubungan secara linear. Karena nilai sig. uji linearitas $=$ 0,606 lebih besar dari pada $\alpha=0,05$, maka hubungan antara variabel kecerdasan emosional dan hasil belajar matematika siswa linear.

Berikut scatter plot antara kecerdasan emosional dan hasil belajar matematika siswa kelas VIII MTs Negeri 1 Kendari.

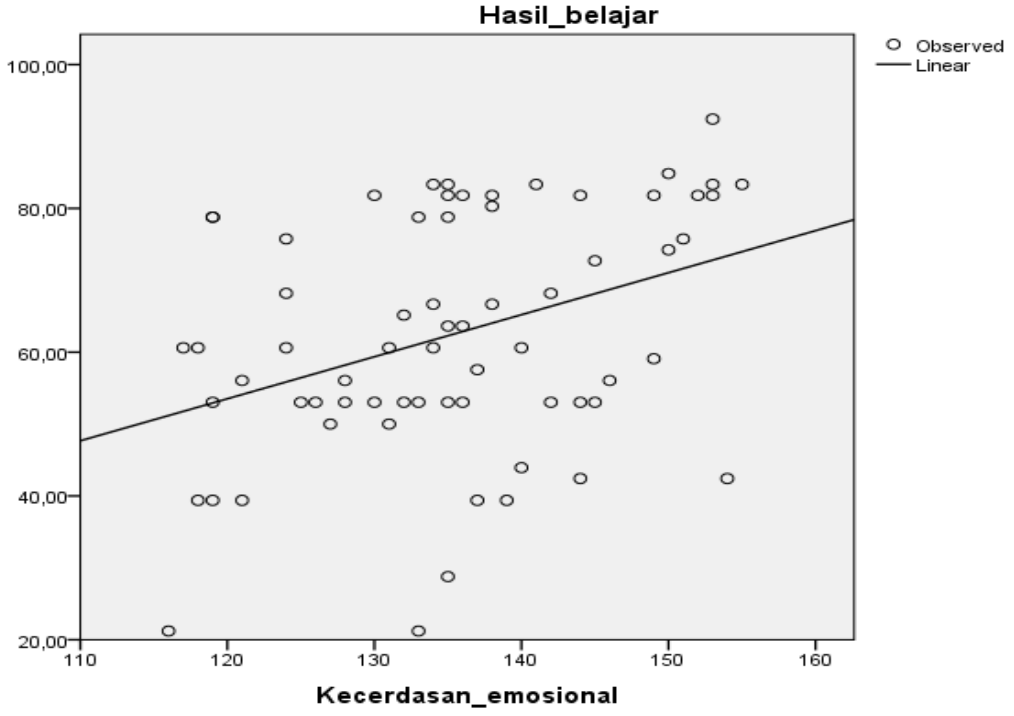

Gambar 2. Scatter Plot

Berdasarkan Gambar 2, titik-titik yang tersebar pada garis lurus (linear) menunjukan banyak data responden (siswa). Data-data tersebut berada disekitar garis linear. Terlihat bahwa garis linear tersebut bergerak dari kiri bawah ke kanan atas. Hal ini berarti kecerdasan emosional dan hasil belajar matematika siswa cenderung memiliki hubungan positif. Artinya semakin tinggi kecerdasan emosional siswa maka hasil belajar yang diperoleh cenderung semakin tinggi, tapi mungkin ada faktor lain yang berpengaruh. Garis datar (sumbu $\mathrm{x}$ ) menunjukan kecerdasan emosional sedangkan garis tegak (sumbu y) adalah hasil belajar matematika siswa.

\section{Pengujian hipotesis penelitian}

Analisis selanjutnya ialah menguji hipotesis dengan menggunakan analisis regresi linear sederhana yang hipotesisnya dijelaskan sebagai berikut. Hipotesis berbunyi "Kecerdasan emosional mempunyai pengaruh yang positif dan signifikan terhadap hasil belajar matematika siswa kelas VIII MTs Negeri 1 Kendari”. Secara statistik, hipotesis tersebut dapat ditulis sebagai berikut.

- $\mathrm{H}_{0}: \quad \beta \leq 0$ (Kecerdasan emosional tidak mempunyai pengaruh yang positif dan signifikan terhadap hasil belajar matematika siswa Kelas VIII MTs Negeri 1 Kendari)

- $\mathrm{H}_{1}: \quad \beta>0$ (Kecerdasan emosional mempunyai pengaruh yang positif dan signifikan terhadap hasil belajar 
matematika siswa Kelas VIII MTs Negeri 1 Kendari)

Pengujian hipotesis dilakukan dengan menggunakan regresi linear sederhana dengan bantuan software statistik SPSS. Berikut tabel koefisien regresi yang tertera pada Tabel 7.

Tabel 10

Koefisien Regresi

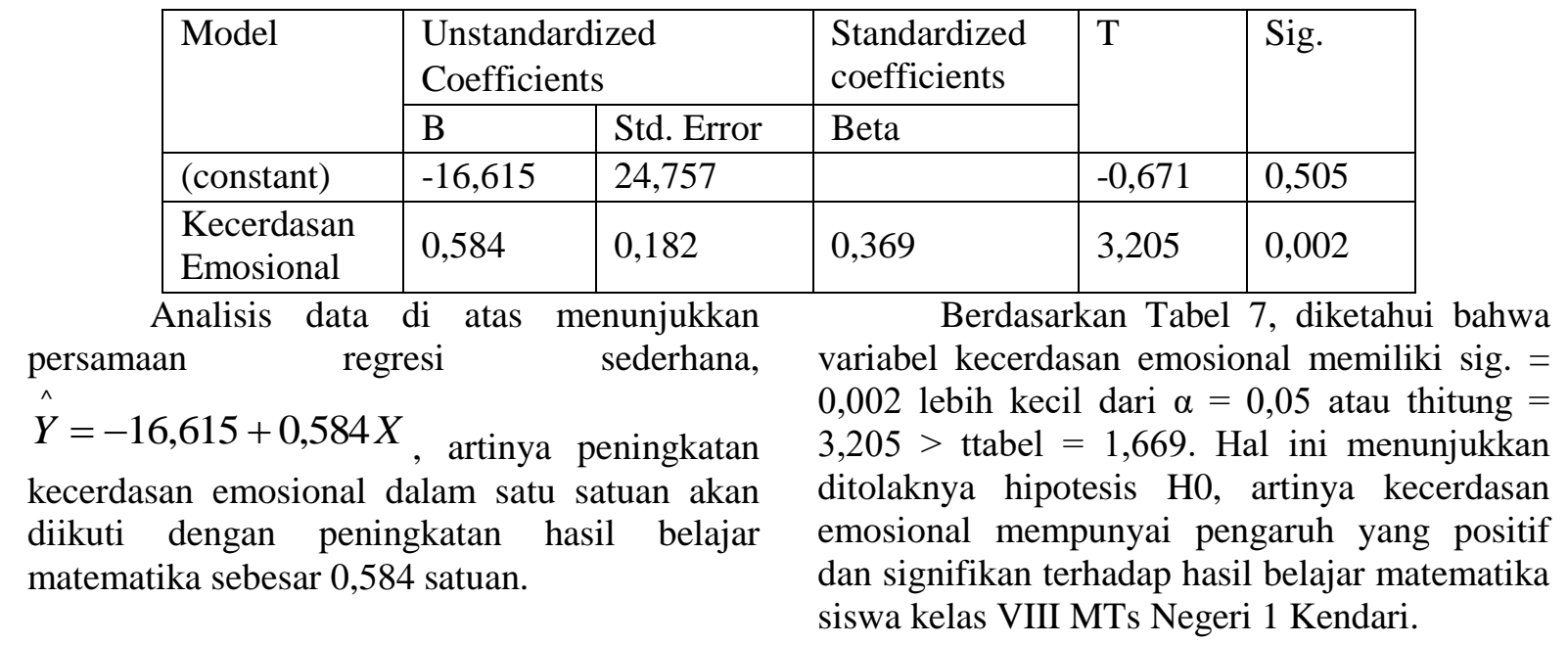

Tabel 11

Model Summary

\begin{tabular}{|l|l|l|l|l|}
\hline Model & $\mathrm{R}$ & $\mathrm{R}$ Square & $\begin{array}{l}\text { Adjusted R } \\
\text { Square }\end{array}$ & $\begin{array}{l}\text { Std. Error of } \\
\text { the Estimate }\end{array}$ \\
\hline 1 &, $369 \mathrm{a}$ &, 136 &, 123 & 15,705 \\
\hline \multicolumn{4}{|c|}{ a. Predictors: (Constant), Kecerdasan_emosional } \\
\hline
\end{tabular}

Tabel analisis di atas menunjukkan bahwa $\mathrm{r}^{2}$ atau $\mathrm{R}$ Square sebesar 0,136 yang menandakan bahwa faktor kecerdasan emosional hanya memberikan pengaruh atau konstribusi terhadap hasil belajar matematika sebesar $13,6 \%$, sedangkan $86,4 \%$ selebihnya dipengaruhi oleh faktor-faktor lain yang tidak diteliti dalam penelitian ini.

\section{Pembahasan}

Berdasarkan hasil analisis data yang telah dilakukan, diketahui terdapat pengaruh yang positif antara kecerdasan emosional terhadap hasil belajar matematika siswa. Hal ini berarti kecerdasan emosional dapat dijadikan sebagai prediktor untuk memprediksi atau mengukur hasil belajar matematika siswa.

Penelitian ini diambil sampel sebanyak 67 siswa kelas VIII yang terbagi atas 34 siswa kelas VIII-5 dan 33 siswa kelas VIII-9. Secara keseluruhan hasil analisis deskriptif variabel kecerdasan emosional siswa kelas VIII MTs Negeri 1 Kendari yang terdiri dari 67 siswa diperoleh skor rata-rata (mean) yang diperoleh sebesar 135,33, ini berarti nilai dari kecerdasan emosional siswa berada pada kategori tinggi. Dengan standar deviasi 10,599, nilai median 135 artinya setengah dari kelas VIII nilai kecerdasan emosional di atas 135 dan setengah lagi di bawah 135. Nilai tertinggi (nilai maksimum) diperoleh sebesar 155 dan nilai terendah (nilai minimum) sebesar 116.

Pada variabel hasil belajar matematika dari 67 siswa diperoleh nilai rata-rata (mean) sebesar 62,480 ini berarti nilai dari hasil belajar matematika siswa berada pada kriteria cukup. Dengan standar deviasi 16,772 , nilai median 60,610 artinya setengah dari kelas VIII nilai hasil belajarnya di atas 60,610 dan setengah lagi di bawah 60,610. Nilai tertinggi (nilai maksimum) diperoleh sebesar 92,42 dan nilai terendah (nilai minimum) sebesar 21,21.

Berdasarkan Tabel 6, dapat dilihat bahwa kecerdasan emosional siswa kelas VIII-5 terdiri atas 2 siswa $(5,88 \%)$ memiliki kecerdasan emosional kategori sangat tinggi, 26 siswa $(76,47 \%)$ memiliki kecerdasan emosional 
kategori tinggi dan 6 siswa $(17,65 \%)$ memiliki kecerdasan emosional kategori sedang. Untuk siswa kelas VIII-9 terdiri atas 25 siswa $(75,76 \%)$ memiliki kecerdasan emosional kategori tinggi, dan 8 siswa $(24,24 \%)$ memiliki kecerdasan emosional kategori sedang. Secara keseluruhan kecerdasan emosional siswa kelas VIII MTs Negeri 1 Kendari terdiri atas 2 siswa $(2,98 \%)$ memiliki kecerdasan emosional kategori sangat tinggi, 51 siswa $(76,12 \%)$ memiliki kecerdasan emosional kategori tinggi, dan 14 siswa $(20,90 \%)$ memiliki kecerdasan emosional kategori sedang.

Hasil di atas menunjukan bahwa siswa kelas VIII MTs Negeri 1 Kendari berada pada kategori kecerdasan emosional tinggi dan kecerdasan emosional sedang. Hampir sebagian besar siswa kelas VIII berada pada kategori kecerdasan emosional tinggi. Jika kita bandingkan antara kelas VIII-5 dan VIII-9 ternyata kelas VIII-9 lebih pada ketegori kecerdasan emosional sedang dibandingkan kelas VIII-5. Namun, kelas VIII-5 lebih banyak kategori kecerdasan emosional tinggi bila dibandingkan dengan kelas VIII-9. Siswa yang memiliki kecerdasan emosional yang tinggi akan mampu memusatkan perhatian dalam memahami materi pelajaran, memotivasi diri sendiri untuk terus maju, memiliki hubungan yang baik dengan orang lain, dan memiliki hasil belajar yang baik. Hal ini sesuai dengan apa yang dinyatakan oleh Mustaqim (2012: 152), kecerdasan emosional dapat berpengaruh dalam proses dan keberhasilan belajar siswa, tanpa adanya kecerdasan emosional siswa akan mudah menyerah, tidak memiliki motivasi belajar dan tidak pandai memusatkan perhatian pada materi pembelajaran.

Distribusi frekuensi hasil belajar matematika siswa kelas VIII-5 MTs Negeri 1 Kendari pada materi lingkaran menunjukan bahwa siswa yang hasil belajarnya sangat baik sebanyak 1 siswa $(2,94 \%)$, siswa yang hasil belajarnya baik sebanyak 21 siswa $(61,77 \%)$, siswa yang hasil belajarnya cukup sebanyak 7 siswa (26,47\%), sedangkan siswa yang hasil belajarnya kurang sebanyak 3 siswa $(8,82 \%)$. Kelas VIII-9 menunjukan bahwa siswa yang hasil belajarnya baik diperoleh sebanyak 2 siswa $(6,06 \%)$, siswa yang hasil belajarnya cukup sebanyak 12 siswa $(36,36 \%)$, sedangkan siswa yang hasil belajarnya kurang sebanyak 19 siswa $(57,58 \%)$. Dengan demikian secara keseluruhan hasil belajar matematika siswa kelas VIII MTs Negeri 1 Kendari pada materi lingkaran menunjukan bahwa siswa yang hasil belajarnya sangat baik sebanyak 1 siswa $(1,49 \%)$, siswa yang hasil belajarnya baik sebanyak 23 siswa $(34,33 \%)$, siswa yang hasil belajarnya cukup sebanyak 21 siswa $(31,34 \%)$, sedangkan siswa yang hasil belajarnya kurang sebanyak 22 siswa $(32,84 \%)$.

Mata pelajaran matematika merupakan mata pelajaran yang dianggap sulit oleh kebanyakan siswa. Hal ini dikarenakan masalahmasalah dalam matematika membutuhkan tahap penyelesaian yang sistematis. Prihandoko (2006: 9) mengemukakan bahwa matematika merupakan mata pelajaran yang berkenaan dengan struktur-struktur, hubungan-hubungan, dan konsep-konsep abstrak yang dikembangkan menurut aturan yang logis. Sehingga, untuk memahami dan menyelesaikan masalah matematika dibutuhkan konsetrasi, kesabaran dan ketelitian yang baik.

Hal ini menunjukkan bahwa dalam menyelesaikan masalah dalam mata pelajaran matematika diperlukan konsentrasi, kesabaran, dan ketelitian yang baik. Dalam mengelola konsentrasi, kesabaran dan ketelitian dibutuhkan motivasi dan pengelolaan emosi yang kuat, sehingga siswa tidak mudah putus asa dan menyerah ketika belum dapat menemukan jawaban penyelesaian yang tepat. Berdasarkan penjelasan tersebut, kecerdasan emosional dapat memberikan sumbangan yang bermanfaat dalam mengelola emosi diri untuk dapat memusatkan perhatian untuk memahami materi pelajaran matematika, serta tetap optimis dan memotivasi diri dalam memperoleh hasil belajar matematika yang baik.

Pengaruh kecerdasan emosional terhadap hasil belajar matematika siswa kelas VIII MTs Negeri 1 Kendari diperoleh dengan melakukan uji hipotesis menggunakan teknik analisis regresi linear sederhana dengan bantuan program SPSS. Namun, sebelum dilakukan uji hipotesis terlebih dahulu dilakukan uji prasyarat analisis yang meliputi uji normalitas data kecerdasan emosional dan hasil belajar matematika, selanjutnya uji linearitas untuk mengetahui apakah kecerdasan emosional dan hasil belajar matematika mempunyai hubungan garis linear.

Hasil uji normalitas data menggunakan uji kolmogorov-smirnov, memberikan hasil 
bahwa sampel variabel kecerdasan emosional dan variabel hasil belajar matematika berasal dari populasi yang berdisribusi normal. Berdasarkan Tabel 9, hasil uji linearitas yang diperoleh ialah variabel kecerdasan emosional (X) dan variabel hasil belajar matematika (Y) berhubungan secara linear.

Berdasarkan gambar 2 (scatter plot), titik-titik yang tersebar pada garis lurus (linear) menunjukan banyak data responden (siswa). Data-data tersebut berada disekitar garis linear. Garis linear tersebut bergerak dari kiri bawah ke kanan atas. Hal ini berarti kecerdasan emosional dan hasil belajar matematika siswa cenderung memiliki hubungan positif. Artinya semakin tinggi kecerdasan emosional siswa maka hasil belajar yang diperoleh cenderung semakin tinggi, tapi mungkin ada faktor lain yang berpengaruh. Garis datar (sumbu x) menunjukan kecerdasan emosional sedangkan garis tegak (sumbu y) adalah hasil belajar matematika siswa.

Hasil dari pengujian hipotesis diperoleh persamaan regresi linear $\hat{Y}=-16,615+0,584 X$, artinya peningkatan kecerdasan emosional akan diikuti dengan peningkatan hasil belajar matematika atau penurunan kecerdasan emosional juga akan diikuti dengan penurunan hasil belajar matematika. Peningkatan kecerdasan emosional dalam satu satuan akan diikuti dengan peningkatan hasil belajar matematika sebesar 0,369 .

Hasil akhir penelitian menyatakan terdapat pengaruh yang positif dan signifikan antara kecerdasan emosional terhadap hasil belajar matematika siswa dilihat dari nilai sig. $0,002>\alpha=0,05$ atau $t_{\text {hitung }}=3,205>t_{\text {tabel }}=$ 1,669 . Besarnya pengaruh kecedasan emosional terhadap hasil belajar matematika dapat dilihat dari nilai $R$ Square yang diperoleh yakni 0,136 . $R$ Square sebesar 0,136 menandakan bahwa faktor kecerdasan emosional hanya memberikan pengaruh atau konstribusi terhadap hasil belajar matematika sebesar $13,6 \%$, sedangkan $86,4 \%$ selebihnya dipengaruhi oleh faktor-faktor lain yang tidak diteliti dalam penelitian ini.

Hasil penelitian yang dilakukan menunjukkan bahwa siswa yang memiliki kecerdasaan emosional tinggi tidak selalu memiliki hasil belajar matematika yang tinggi pula. Terdapat siswa yang kecerdasaan emosionalnya tinggi tetapi memiliki hasil belajar matematika pada kategori cukup dan kurang. Hal ini menunjukkan bahwa kecerdasaan emosional bukan satu-satunya faktor yang dapat meningkatkan hasil belajar metematika, masih terdapat faktor-faktor lain yang dapat mempengaruhi hasil belajar matematika siswa.

Hal ini sesuai dengan apa yang dinyatakan oleh Goleman (2016: 42) yang menyatakan bahwa IQ hanya mempunyai peran sekitar $20 \%$ dalam menentukan prestasi individu, $80 \%$ sisanya ditentukan oleh faktorfaktor lain termasuk kecerdasan emosional. Berdasarkan penjelasan di atas, dapat disimpulkan bahwa tedapat pengaruh yang positif dan signifikan antara kecerdasan emosional terhadap hasil belajar matematika siswa kelas VIII MTs Negeri 1 Kendari.

\section{Simpulan dan Saran}

\section{Simpulan}

Berdasa

rkan hasil analisis dan pembahasan yang diperoleh maka dapat disimpulkan bahwa :

1. Kecerdasan emosional siswa kelas VIII MTs Negeri 1 Kendari terdiri atas 2 siswa $(2,98 \%)$ memiliki kecerdasan emosional kategori sangat tinggi, 51 siswa $(76,12 \%)$ memiliki kecerdasan emosional kategori tinggi, dan 14 siswa $(20,90 \%)$ memiliki kecerdasan emosional kategori sedang.

2. Hasil belajar matematika siswa kelas VIII MTs Negeri 1 Kendari menunjukan bahwa siswa yang hasil belajarnya sangat baik sebanyak 1 siswa $(1,49 \%)$, siswa yang hasil belajarnya baik sebanyak 23 siswa $(34,33 \%)$, siswa yang hasil belajarnya cukup sebanyak 21 siswa $(31,34 \%)$, sedangkan siswa yang hasil belajarnya kurang sebanyak 22 siswa $(32,84 \%)$.

3. Kecerdasan emosional siswa mempunyai pengaruh yang positif dan signifikan terhadap hasil belajar matematika siswa kelas VIII MTs Negeri 1 Kendari, besarnya pengaruh kecerdasan emosional yaitu $13,6 \%$, sedangkan sisanya sebesar $86,4 \%$ dipengaruhi oleh faktor lainnya yang tidak diteliti dalam penelitian ini.

\section{Saran}

Berdasa

rkan pembahasan dan kesimpulan hasil 
penelitian, maka penulis memberikan saransaran sebagai beriku:

1. Kecerdasan emosional mempunyai pengaruh dalam upaya menunjang peningkatan hasil belajar dan perkembangan perilaku yang positif, untuk itu guru dan orang tua memiliki peran yang penting dalam memotivasi siswa agar dapat bersikap optimis dalam pelajaran matematika sehingga dapat memiliki hasil belajar matematika yang lebih baik.

2. Bagi siswa, hendaknya lebih bersemangat untuk belajar, lebih tekun, dan pantang menyerah ketika menghadapi soal-soal matematika mengingat matematika merupakan salah satu mata pelajaran yang selalu ada pada setiap jenjang pendidikan.

\section{Daftar Pustaka}

Dermawan, Deni. (2013). Metode Penelitian Kuantitatif. Bandung: PT Remaja Rosdakarya.

Goleman, Daniel. (2016). Emotional Intelligence: Mengapa EI Lebih Penting daripada IQ. Jakarta: Gramedia Pustaka Utama.

Imron, Muhammad. (2016). Pengaruh Kecerdasan Emosonal, Kecerdasan Spiritual, Kecerdasan Intelektual dan Perilaku Belajar terhadap Prestasi Belajar Matematika Siswa Madrasah Aliyah. UHO: tidak ditebitkan.

Jihad, Asep \& Haris, Abdul. (2013). Evaluasi pembelajaran. Yogyakarta: Multi Presindo.

Mustaqim. (2012). Psikologi Pendidikan. Yogyakarta: Pustaka Pelajar.

Prawira, Purwa Atmaja. (2013). Psikologi Pendidikan dalam Perspektif Baru. Jakarta: Ar-Ruzz Media.

Prihandoko, Antonius Cahya. (2006). Memahami Konsep Matematika secara Bendar dan Menyajikannya dengan Menarik. Jakarta: Departemen Pendidikan Nasional.
Salovey, dan Mayer J. (2004). Emotional Intellidence. Jakarta: PT Gramedia Pustaka Utama.

Siregar, Syofian. (2013). Metode Penelitian Kuantitatif: Dilengkapi Pebandingan Perhitungan Manual \& SPSS. Jakarta: Kencana.

Sugiyono. (2009). Metode Penelitian Kuantitatif, Kualitatif dan $R \& D$. Bandung: Alfabeta.

Thobroni, Muhammad dan Arif Mustofa. (2013). Belajar dan Pembelajaran: Pengembangan Wacana dan Praktik Pembelajaran dalam Pembangunan Nasional. Yogyakarta: Ar-Ruzz Media.

Yusuf, Syamsu. (2004). Psikologi Perkembangan Anak dan Remaja. Bandung: PT. Remaja Rosdakarya 